\title{
Yahudi Nüfus Problemi ve İsrail Devleti’nin Yahudi
} Karakteri

\section{Menderes KURT}

\section{Öz}

Bu çalışmanın amacı, İsrail'in kurulması ve varlığını sürdürmesi noktasında temel taşlardan biri olan "nüfus/demografi" olgusunun günümüzdeki halinin, İsrail sınır ve vatandaşlık politikası üzerinde hâlihazırda ve yakın gelecekte yaratığı/yaratabileceği ihtimalleri analiz etmektir. Siyonizmin ilk dönemlerinden itibaren misyon edindiği Filistin'de kurulacak devletin demografik anlamda çoğunluğu sağlama amacına (Yahudi karakterde bir devlet) ulaşmış olmasına rağmen 2018-2019 yılı İsrail nüfus verileri ışığında bu olgunun değişmeye başladığı görülmektedir. Ayrıca yakın gelecekte tarihî Filistin bölgesi göz önüne alındığında, Filistinli (Arap) nüfusunun Yahudi nüfusunu geçeceği tahmin edilmektedir. İsrail Devleti'nin oluşumu ve varlığını sürdürme noktasında temel taşlardan biri olan devletin demografik anlamda Yahudi çoğunluğunu sağlama ve koruma misyonu, tehdit altındadır. Bu minvalde çalışma, devletin ulusal güvenliğiyle bağlantılı nüfus olgusunda yaşanan değişim sonucunda İsrail'in devletin Yahudi karakterini korumak için hem vatandaşlık temsilinde hem de devletin sınırları noktasında Yahudileştiğini iddia etmektedir. Bu noktada "Yüzyılın Anlaşması" ve "Yahudi Ulus Devleti Yasası" gibi gelişmeler, Arap nüfusundaki artışın yükünü kaldırmakta zorlanan devletin hem fiziksel/sınır hem de vatandaşılı manasında bir homojenleşmeye (Yahudileşme) gittiğinin ve kendisini keskin bir şekilde Filistinlilerden soyutlama isteğinin göstergeleridir. Bu çerçevede çalışma, tarihsel olarak İsrail'in nüfus politikası ve günümüz verileri ışı̆̆ında İsrail'in nüfus sorununa eğilmeyi amaçlamaktadır.

Anahtar Kelimeler: İsrail, Araplar, Yahudiler, Nüfus, Yahudileştirme. 


\title{
The Jewish Population Problem and the Jewish Character of the State of Israel
}

\begin{abstract}
The aim of this study is to analyze the current state of the phenomenon of "population/demography", which is one of the cornerstones of Israel's formation and survival, on Israeli policy now and soon. Despite the fact that the state to be established in Palestine, where Zionism has taken a mission since the early periods, has achieved the goal of providing a demographic majority (a state with a Jewish character), this phenomenon has started to change in the light of 2018-2019 Israeli population data and in the near future, when the whole historic Palestinian region is considered, it is estimated that the Palestinian (Arab) population will exceed the Jewish population. The mission of ensuring and protecting the demographic Jewish majority, one of the cornerstones of the formation and survival of the state of Israel, is under threat. In this manner, because of the change in the population phenomenon linked to the national security of the state, Israel Judaizes both in its representation of citizenship and at the borders of the state to preserve the Jewish character of the state. At this point, developments such as the "Deal of the Century" and the "Israel as the Nation-State of the Jewish People" are indications that the state, which struggling to bear the burden of the increase in the Arab population, went to a homogenization (Judaization) in terms of both physical/border and citizenship and its desire to isolate itself from the Palestinians sharply. In this context, the study aims to deal with Israel's population problem in the light of historical Israeli population policy and today's data.
\end{abstract}

Keywords: Israel, Arabs, Jews, Population, Judaization.

\section{Extended Abstract}

This study aims to analyze the current state of the phenomenon of "population/demography", which is one of the cornerstones of Israel's establishment and survival, on Israeli policy now and soon. Even though the state to be established in Palestine, where Zionism has taken a mission since the early periods, has achieved the goal of providing a demographic majority (a state with a Jewish character), this phenomenon has started to change in the light of 2018-2019 Israeli population data and soon, when the whole Palestinian region is considered, it is estimated that the Palestinian (Arab) population will exceed the Jewish population. While the population is a problematic phenomenon for Israel, the existence of the problem has historical continuity. Although today Israel maintains a Jewish majority in the Palestinian geography, this situation tends to change soon. In a demographic sense, the change in Israel is expected to lead to significant changes in the state's political attitudes and decisions, especially in relations with Arabs. The population problem in Israel is closely linked to 
the Jewish character of the state. A population change endangers historical thinking, one of Israel's cornerstones. In addition to historical thinking, demographic change is directly linked to Israeli national security. Demographic change in Israel opens the door to important political changes in terms of Israel's Jewish character and national security. Developments such as the "Deal of the Century" project announced under the leadership of the USA, Basic Law: Israel as the Nation-State of the Jewish People, the move of the US Embassy to Jerusalem, and the annexation of the Golan Heights, are all manifestations of the recent political development. In this context, the study tries to understand the change in Israeli policy within the framework of historical data and current (2018-2019) qualitative and quantitative demographic data. At this point, the study claims that the demographic change in Israel poses a threat to Israel's Jewish character and national security. In other words, the study claims that the mission of the state, which is one of the cornerstones of the formation and survival of the State of Israel, to provide and protect the Jewish majority in demographic terms is under threat. At this point, developments such as the "Deal of the Century" and the "Israel as the Nation-State of the Jewish People" are indications that the state, which is struggling to bear the burden of the increase in the Arab population, preferred a policy of homogenization (Judaization) in terms of both physical / border and citizenship and its desire to drastically isolate itself from the Palestinians. As a matter of fact, its intention to evolve into a homogeneous Jewish society by isolating itself from the Palestinians to a certain extent obliges the Israeli policy to rely on a Jewish nationalist and religious structure. The demographic factor is the main determining factor in the political developments in countries such as Israel, where the Jewish population and the character of the state are tightly connected to each other. Despite this, the demographic element remains in the background in the traditional forms of explanation regarding the political developments and changes in Israel. Traditional forms of explanation mostly focus on ideology, leaders, geopolitics, and specific groups. In this sense, the principle of protecting the Jewish character of the state, that is, the principle that Jews should be the majority population in Israel, which is directly related to the national security of the state in the historical sense, does not find a place for itself in traditional explanations. However, the population issue in Israel and the Jewish character of the state, which is directly related to it, have remained important in terms of political thought and political developments in Israel. Within the framework of the classical method in demographic studies, the study evaluates the rates of Jewish and Arab populations and their growth rates. In this context, the study aims to understand the implications of demographic change for Israeli politics and national security and the possibilities that it can create within the framework of historical background, rather than revealing the Israeli demographic change in all its aspects (its effects on land, agriculture, technology, energy, and education). It also aims to measure the impact of the demographic element on Israeli policy and national security. For this, the study primarily examines the historical link between the Jewish character of the state and the population phenomenon in Israel. In this 
respect, the study reveals the role of the population phenomenon in the shaping of the state and the formation of the Jewish character with qualitative and quantitative data. Then, in the light of current population data and discussions, the connection of the population problem in Israel with political preferences and developments is discussed. 


\section{Giriş}

Bu çalışmanın amacı, İsrail'in kurulması ve varlığını sürdürmesi noktasında temel taşlardan biri olan "nüfus/demografi" olgusunun İsrail politikası üzerinde hâlihazırda ve yakın gelecekte yarattığı/yaratabileceği ihtimalleri analiz etmektir. İsrail için nüfus, problem teşkil eden bir olgu olmakla birlikte problemin varlığı tarihsel süreklilik taşımaktadır. Bugün İsrail, tarihî Filistin coğrafyasında (Ürdün Nehri'nden Akdeniz'e uzanan bölge) nüfus olarak Yahudi çoğunluğu sağlamasına rağmen bu durum yakın gelecekte değişme eğilimi göstermektedir. Demografik manada İsrail'de yaşanan değişimin devletin politik tutum ve kararlarında, özellikle de Araplarla olan ilişkilerinde önemli değişikliklere yol açması beklenmektedir. İsrail'de nüfus problemi devletin Yahudi karakteri ile yakından bağlantılıdır. Bu nedenle nüfusta yaşanan bir değişim İsrail'in üzerinde temellendiği tarihsel düşüncenin tehdit altına girmesine neden olmaktadır. Tarihsel düşünceye ek olarak demografik değişim İsrail ulusal güvenliği ile doğrudan bir bağa sahiptir. İsrail'deki demografik değişim İsrail'in Yahudi karakteri ve ulusal güvenliği açısından önemli politik değişimlere gebedir. ABD liderliğinde açıklanan Yüzyılın Anlaşması projesi, Yahudi Ulus Devlet Yasası, ABD Büyükelçiliği'nin Kudüs'e taşınması ve Golan tepelerinin ilhakının Amerika tarafından tanınması gibi gelişmeler, İsrail'in hem fiziksel hem de vatandaşlık manadaki homojenleşmesinde (Yahudileşme) yaşanan ve yaşanacak politik değişimi ortaya koymaya başlamıştır. Bu bağlamda çalışma tarihsel (1882-2000) ve güncel (2018-2019) nitel ve nicel demografik veriler çerçevesinde bu değişimin takibini yapacaktır. Bu noktada çalışma, İsrail'deki demografik değişimin İsrail’in Yahudi karakteri ve ulusal güvenliği açısından tehdit oluşturduğunu iddia etmektedir. Başka bir ifadeyle çalışma İsrail Devleti'nin oluşumu ve varlığını sürdürme noktasında temel taşlarından biri olan devletin demografik anlamda Yahudi çoğunluğunu sağlama ve koruma misyonunun tehdit altında olduğunu iddia etmektedir. İsrail, artık kontrol etmekte zorlandığı nüfus problemi nedeniyle devletin sınırlarını (Yüzyılın Anlaşması ve ilhaklar), kimliğini (Yahudi Ulus Devlet Yasası) belli ölçülerde belirleyerek kendisini Filistinlilerden soyutlayarak homojen bir Yahudi toplumu elde etme yoluna gitmektedir.

Yahudi nüfusu ve devlet karakterinin birbirine sıkı bir şekilde bağlı olduğu İsrail gibi ülkelerde yaşanan politik gelişmelerde demografi unsuru belirleyici unsurların başında gelmektedir. Buna rağmen İsrail'deki politik gelişmelere ve değişimlere dair ortaya konulan geleneksel açıklama biçimlerinde demografi unsuru arka planda kalmaktadır. Geleneksel açıklama biçimleri çoğunlukla ideoloji, lider, jeopolitik ve belli gruplara odaklanmaktadır. Bu minvalde tarihsel anlamda devletin ulusal güvenliği ile doğrudan bağlantılı devletin Yahudi karakterini koruma, yani Yahudilerin İsrail'de nüfus olarak çoğunlukta olması gerektiği prensibi geleneksel açıklamalarda kendisine yer bulmamaktadır. Bu prensibe çoğunlukla İsrail'in kuruluş dönemine dair yapılan açıklamalarda değinilmektedir. Fakat İsrail'de nüfus meselesi ve onunla doğrudan bağlantılı 
olan devletin Yahudi karakteri olgusu İsrail politik düşüncesinde ve İsrail'deki politik gelişmelerde önemini korumuştur. ${ }^{2}$

Demografi unsurunun İsrail'de yaşanan gelişmeleri açıklama noktasında geri planda kalmasında demografi çalışmalarının yapısı ile de doğrudan bağlantılıdır. Demografi çalışmaları çoğunlukla bir ülkenin nüfusa oranla kaynaklarını ayarlama, ülkenin politik yapısı, ülkenin yeterli insan gücüne sahip olması ve göç alıyorsa bunun ülkeye ağırlığı gibi birçok konu ile bağlantılıdır. Pek çok devlet için bu çalışmalar ülkenin gelecek planlaması, kaynak dağıtımını planlama noktasında önem taşımaktadır (Cox, 1976; Saenz, Embrick ve Rodriquez, 2015). Ayrıca demografi ile ulusal güvenlik arasında bu minvalde doğrudan bir bağlantı kurulmaktadır. Nitekim İsrail üzerine yapılan demografi çalışmaları çoğunlukla diğer devletlerde olduğu gibi demografi ve kaynakların yeterliliği gibi konular üzerine odaklanmaktadır. ${ }^{3}$ Bu minvalde demografinin bir ülkenin ulusal güvenliği için taşıdığı önem tartışılmaz. Ayrıca ülkenin üzerinde temellendiği ideolojik düşünceyle doğrudan bir bağa sahiptir (Weiner ve Russell, 2001: 3). Her ülkenin üzerinde temellendiği bir etnik ideolojik yapı olmasına rağmen İsrail açısından nüfus ve devletin varlığının devamlılı̆̆ı arasındaki bağ hayati bir konumdadır. Özellikle Filistin'de Arap nüfusundaki hızlı artış, İsrail'deki politik gelişmelerde etnik yapı ve demografi arasındaki bağın hayatiyetini ve İsrail'in farklılığını ortaya koymaktadır.

Demografi ve etnik ideolojik yapı, devletin temel karakteri arasındaki bağ noktasında İsrail'in neden farklılaştığını ise Weiner ve Russell'in ortaya koymuş olduğu model üzerinden anlaşılabilir. Devletlerin nüfus değişimine -özellikle de iki baskın etnik kimlikli devletlerin- nasıl cevap verdiğini mezkûr yazarlar üç parametre üzerinden açıklamaktadır. Bu parametreler; askeri güç kullanma, göçmen akımını etkin bir şekilde yönetme ve son olarak vatandaşlığın yasal karakterini ve devletin sınırlarını belirleme şeklindedir (Weiner ve Russell: 2001). İlk iki parametre İsrail çalışmalarında büyük oranda incelenmiştir. Demografinin ulusal güvenlikle doğrudan ilişkilendirildiği İsrail gibi ülkelerde, demografik değişim durumlarında vatandaşlığın yasal karakterini ve devletin sınırlarını belirleme parametresi uygun bir açıklama sunmaktadır. Nitekim bu parametre İsrail demografisinde yaşanan değișim sonucunda anlam kazanmaya başlamıştır.

\footnotetext{
2 Bu noktada Gökhan Çınkara ve Özgür Dikme'nin yapmış olduğu çalışmalar önemli bir boşluğu doldurmaktadır. Çınkara'nın Yahudi Ulus Devleti yasası çerçevesinde İsrail'deki demografik, jeopolitik ve özellikle elit ve kurum düzeyinde tarihsel ve dönüşümü üzerinden yapmış olduğu analiz önemlidir. Çınkara, 2020, ss. 191-202, Ayrıca bkz. Dikmen, 2019, Goldscheider, 1995, ss. 119-144.

3 Bu noktada Alan Tal'in yapmış olduğu çalışmalar ön plana çıkmaktadır. İsrail'deki demografik artış, doğal kaynak yeterliği ve Yahudi göçü ilişkisindeki paradoks üzerine yazmış olduğu The Land is Full çalışma konuya dair geniş bilgi sunmaktadır. Tal, 2016; ayrıca bkz. Ben-David, 2018 ve 2019. İsrail'e odaklanan demografi çalışmaları ayrıca İsrail'deki bölünmüş yapıyı ve bu yapının etnik grupların siyasete etkisini ortaya koyma noktasında içsel bir yönelişi de bulunmaktadır. Bu noktada bu çalışmalar Yahudi-Arap temel ayrımından çok demografi unsurunun İsrail'deki grupların -dindar ve seküler, Harediler, Rus Yahudiler, Falaşalar olarak bilinen Etiyopyalı Yahudiler, Seferadlar ve Askenaziler vb-. toplum ve siyaset ile olan ilişkileri üzerindeki etkisini anlamaya odaklanmaktadır. Temel olarak bkz. Goldscheider, 1996, 1992 ve 1995; Hovsepian, 2015; Bar-Haim, 2015; Israel's Religiously Divided Soviety, 2016.
} 
Buna göre milli kimliği korumak için vatandaşlık kimliği devletle özdeştirilmekte ve devletin sınırları belirginleștirilmektedir. Demografik anlamda yükselişte olan etnik grubun önüne engeller koyarak ve hâkim grubun kültür ve değerlerini yasal güvence altına alarak demografik değişimin statükoya getirdiği tehdit aşılmaya çalışılır. Bu noktada İsrail'de Yahudi Ulus Devlet Yasası, Yüzyılın Anlaşması ve bunları takip eden ilhaklar gibi gelişmeler bu parametre çerçevesinde ele alınacaktır.

Demografi çalışmaları bir ülkenin geçmişte, hâlihazırda ve gelecekte yapı olarak durumunu analiz etme imkânı sağlar. Nitekim bu minvaldeki analizlerin hassasiyeti ve şüphe unsuru, özellikle geleceğe yönelik analizlerde, her zaman hesaba katılmalıdır. Bu nedenle demografi temelli yapılan analizler geçerli veri ve metot üzerinden inşa edilmelidir. Bu noktada demografi üzerinden yapılan tahminler nüfusun toplam verileri ve yapının işleyiş şekli üzerinden yürütülmelidir. Nüfus artışına neden olan yaş, doğum ve ölüm oranları, nüfus artış hızı gibi olgular karşılaştırmalı bir şekilde düşünülmelidir. Bunlara ek olarak demografik analizlerde zaman olgusu dikkate alınmalıdır. Bu noktada nüfusu etkileyen olguların zaman içerisindeki değişimi üzerinden tahminler yürütülmelidir (Cox, 1976: 9-10). Bu bağlamda ilk olarak elde edilen verilerin karakteri iyi analiz edilmelidir. İkincisi geçmiş tecrübeler ortaya konulmalı ve bu tecrübeyi etkileyen ve değişimine sebep olan etkenler olabildiğince tespit edilmelidir. Daha sonra elde edilen veri ve geçmiş tecrübesi üzerinden ihtimaller ortaya konulmalıdır. Son olarak ise analizin arka planını gösteren sosyoekonomik hatta psikolojik var olan bilgi ile desteklenmelidir. Bu noktada çalışma, verileri baştan oluşturmak yerine var olan verili bilgiyi kullanmaktadır. Demografik çalışmalardaki klasik yöntem çerçevesinde çalışma, Yahudi ve Arap nüfus oranları ve artış hızları üzerinden bir değerlendirme yapmaktadır. Bu bağlamda çalışmanın amacı, İsrail demografik değişimini bütün yönleri ile (toprak, tarım, teknoloji, enerji ve eğitim üzerindeki etkileri) ortaya koymaktan öte, demografik değişimin İsrail politikası ve ulusal güvenliği için taşıdığı anlamı ve yaratabileceği ihtimalleri tarihsel bir arka plan çerçevesinde anlamaktır. Aynı zamanda demografi unsurunun İsrail politikası ve ulusal güvenliği üzerindeki etkisini ölçmektir. Bunun için çalışma öncelikle İsrail'de devletin Yahudi karakteri ve nüfus olgusu arasındaki tarihsel bağı incelemektedir. Bu minvalde devletin şekillenmesi ve Yahudi karakterinin oluşmasında nüfus olgusunun oynadığı rolü nitel ve nicel verilerle ortaya koymaktadır. Daha sonra ise güncel nüfus verileri ve tartışmaları ışığında İsrail'de nüfus probleminin politik tercihler ve gelişmelerle bağlantısı ele alınmaktadır.

\section{Yahudi Nüfus Problemi}

Yahudi nüfus problemi İsrail tarihinin anlaşılmasında önemli bir unsurdur. Ayrıca Yahudi Sorununa çözüm bulmak isteyen siyonistler için önemli bir alt başlığı ihtiva etmektedir. Nitekim problem siyonist hareketin gelişimine paralel 
bir gelişim çizgisi izlemiştir. Siyonistler için Yahudi sorununun çözümü noktasında nüfus problemi, tahayyül edilen Yahudi karakterli devletin kurulmasının temel taşlarından birini oluşturmaktadır. Bu noktada devletin Yahudi karakteri ve nüfus arasındaki paralelliği ortaya koymak için öncelikle Yahudi nüfus problemi nedir? sorusunun cevaplanması gerekmektedir. Yahudi nüfus probleminin iki boyutu bulunmakta ve bunlar siyonizmin nasıl tanımlandığı ile yakından bağlantılıdır. Temel anlamda siyonizm, diasporada yaşamak istemeyen ve yaşayamayan Yahudileri Filistin'e taşımak, dünya üzerinde dağınık ve azınlık olan Yahudilerden "Yahudi karaktere" sahip bir toplum oluşturma idealidir (Reinharz, 1991: 28). İsrail için Yahudi çoğunluğun taşıdığı anlam diğer uluslar gibi güvende, özgür ve kendi iradesine sahip eşit bir ulus olmaktır. Bu tanımlama çerçevesinde Yahudi nüfus problemi, öncelikle tarihsel olarak farklı toplumlar içerisinde azınlık olarak yaşamanın yaratmış olduğu "Yahudi Sorunu” ile ilişkilidir.

İsrail’i doğuran olgu Yahudi sorununu çözme düşüncesidir. Nitekim bu sorunun kaynağı çoğunlukla Yahudilerin dünya üzerinde yaşadıkları bölgelerde azınlık olmalarından kaynaklanmaktaydı. Yahudiler için azınlık olmak aynı zamanda zayıf olmak anlamına gelmektedir (Reinharz, 1991: 28). Bu çerçevede ilk dönem siyonist yazılara bakıldığında, Yahudilerin azınlık olma durumlarından kaynaklı olan zayıflıklarını aşmak için kendi kendilerini çoğunluk olarak yönettikleri bir devlet formülü geliştirilmeye çalıştıkları görülmektedir. Yahudileri çoğunluk oldukları bir devlet kurmaya iten en önemli unsur ise Avrupa'da Yahudilere karşı var olan olumsuz (anti-semitizm) tutumdur ( $\mathrm{Avcl}$, Bahar 2006: 46-48; Çulcu, 2012: 11-14). Bu olumsuz tutum Yahudilerin Eretz-Israil'de yani kısıtlama, baskı ve dışlanmanın olmadığı topraklarda yaşama arzusunu perçinlemiştir. 16. yüzyılda Katolik İspanya baskısından kaçan ve Avrupa'da sürekli takibata maruz kalan ünlü Yahudi hekim ve filozof Isaac Abravanel'in (1437-1508) Venedik'teki mezar taşı üzerinde yer alan özgürlük ve güvenlik arayışında bir ömür ibaresinin dönemin bütün Yahudileri için geçerli olduğu söylenebilir (Ruderman, 2013: 31). 1800'lerin sonlarına Doğru Avrupa'da Yahudi karşıtlığının artmasıyla birlikte Leon Pinsker (1921-1891) gibi siyonist düşünürler, Yahudi devletinin kurulacağı "ulusal merkeze kitlesel göç” fikrini geliştirmiştir. Fakat Pinsker'in kurulmasını hayal ettiği Yahudi devletinin en önemli özelliği Yahudi çoğunluğun sağladığı Yahudi karakterdir (Hertzberg, 1997: 180-198; Avineri, 2017). 1882'de kaleme aldığı Auto-Emancipation isimli eserinde bu fikri şöyle formülleştirmektedir: "Yahudiler hayalet ulus olarak kaldıkça, asimile edilmedikçe, hiçbir yerde ulusal çoğunluk oluşturmadıkça, bu tedavisi olmayan psikoz (anti-semitizm) varlığını sürdürecektir. Yahudiler azınlık oldukları ülkeleri terk etmeleri ve egemen olarak kendilerine ait olan çoğunluk oluşturacakları ulusal bir toprakta yeniden toparlanmaları şarttır" (Pinsker, 1982 naklen Greilsammer, 2007: 35). Theodor Herzl (1860-1904) 1896'da kalem aldığı Yahudi Devleti isimli kitabında Yahudi meselesinin sosyal ve dini değil milli bir nitelik taşıdığını belirtmektedir. Yine ona göre Yahudiler başka ülkelerde azınlık olarak yaşadığı sürece anti-semitizm canlı kalacaktır: "Ne kadar çabalarsa çabalasınlar Yahudilerin 
yaşadıkları ülke toplumlarında tam olarak uyumuna izin verilmeyecek ve daima kaderi çoğunluğun elinde olan yabancı azınlık olarak kalacaktır. Dolayısıyla bu ezilmişliğe, ikinci sınıflığa yegâne çözüm Yahudilerin azınlık kalmaktan kurtulup kendi ülkelerinde çoğunluk olarak yaşamalarıdır" (Herzl, 2007: 31-37).

19. yüzyıl sonlarından 1948 'de İsrail Devleti kurulana kadar dünyanın farklı yerlerinden Yahudiler Filistin'e göç et(tiril)miştir. Filistin'e gerçekleşen bu göçler, İsrail nüfus probleminin ikinci boyutunu doğurmuştur. İsrailli Yahudiler için demografi problemi (ha-ba'aya ha-demografit), sayısal olarak Arapların Yahudileri geçme korkusunu ifade etmektedir. Bu mesele öncelikle Filistin'de Yahudi çoğunluğun nasıl sağlanacağı ve bölgede yaşayan yerli Arap problemi ile nasıl baş edileceğidir. Çünkü burada yaşayan Araplar, siyonist ideolojinin üzerinde temellendiği Yahudilerin çoğunluk olduğu bir devlet fikrini tehdit etmektedir. Bu mesele İsrail tarihinin en önemli tartışmalarına neden olmakla birlikte 1967'den itibaren İsrail politik yaşamında Gazze ve Batı Şeria'nın geleceğinin belirlemesinde öncelikli sorunu teşkil etmektedir. Batı Şeria'nın ilhakı ve ikiye bölünmesi meselesi gündeme geldiğinde azınlık veya çoğunluk bir Arap nüfusu ile ne yapılacağı mevzusu gündeme gelmektedir (Lustick, 2013: 185). Bir tarafta aşırı sağın yeni topraklar kazanarak genişleme arzusu ve İsrail'in artan nüfusuna daha fazla toprak açma ihtiyacı, diğer tarafta ülkede Yahudi çoğunluğu sağlama amacıyla dışarıdan gelen göçmenlere yer açma meselesi, bunların yanında Arap nüfusunu kontrol etme çabası, İsrail için sürekli problem ve çözümü içerisinde barındıran bir paradoks yaratmaktadır.

\section{Nüfus Probleminin Tarihsel Gelişimi}

Nüfus Problemi, Yahudilerin Avrupa'dan Filistin'e kitlesel göçleriyle paralel bir şekilde gelişmiştir. Güçlerle birlikte problemin odak noktasını ise Filistin'deki yerel halk oluşturmuştur. Başka bir ifadeyle, 1882 tarihinden itibaren Filistin'e yapılan göçler ve bu göçler sayesinde bölgede bir devlet kurma meselesi noktasında siyonistlerin karşısındaki en önemli engel, bölgede yaşayan Araplar ile nasıl bir ilişki kurulacağıydı. Arap problemi siyonist fikrin gelişimine paralel bir gelişim çizgisi izlemiştir. Nitekim Filistin'de devlet kurmayı düşünen siyonistler, bölgeye yaptıkları çeşitli seyahatler neticesinde "Arap problemi” ile karşılaşmış ve bunun ileride yaratabileceği sorunların farkına varmışlardır. Bu sorun ise azınlık olma durumundan kurtulmak için Filistin'e kaçarken burada tekrar azınlık olma tehlikesi ile karşı karşıya kalma korkusudur.

Bölgede Yahudi yerleşiminin rahatsızlık yaratacağı, bölgeye göçü teşvik eden siyonistler tarafından aslında beklenilen bir durumdu. Siyonist lider Leon Pinsker "toprağı kardeşlerimizin çalacağını ve ne kadar para verseler kiralamayacaklarını anlayan Fellahların ekmek parası kazanmak için bizimle savaşmaktan başka çareleri var mı?" ifadeleri ile ileriye yönelik doğru bir tahminde bulunmuştur. Aynı şekilde bölgeye iki seyahat düzenleyen önemli siyonist 
düşünürlerden Achad Ha'am (Asher Zvi Hirsch Ginsber, 1856-1927), 1891'de bölgede yaşayan yerlilerin siyonist iddia için önemli sıkıntılar yaratacağını belirtmiştir (Öke, 2013: 73-74). 1891'deki Filistin seyahatine dair günlüklerinde şunları belirtir:

\begin{abstract}
Bizler, yurt dışında Filistin'in neredeyse tamamen boş bir toprak olduğunu, işlenmemiş bir çöl olduğunu, nadasa bırakılmış bir tarla olduğunu, toprak satın almak isteyen herkesin oraya gidip keyfince toprak satın alabileceğini sanıyorduk. Aslında böyle değil; bu topraklar üzerinde ekilmemiş ama işlenebilir bir toprak parçası bulmak güç, plantasyonlara toprak bulmak güç. Arapları salak sanırız ama değiller, kurnazlar. Bizim amacımızı biliyorlar ama tehlike olarak görmüyorlar. Yararlanmak peşindeler. Topraklarını onların hayal bile edemeyeceği fiyatlarla satın alıyoruz. Ama halkımızın varlığının, yerli nüfusun konum üzerinde az çok mütecaviz bir boyut kazanacağı gün, artık yerlerini bize seve seve bırakmayacaklar (Greilsammer, 2007: 93).
\end{abstract}

Bununla birlikte Theodor Herzl de 1898'de bölgeye yaptığı seyahat sırasında hem bölgedeki yerel halkın ileride siyonist düşünce için yaratabileceği sorunların hem de Yahudi göçlerin yerel halk nezdinde yarattığı rahatsızlığın farkına varmıştır. Hatta bölgeden Yahudi göçlerin durdurulmasına dair şikâyet mektupları almıştır. Kudüs Belediye Başkanı Yusuf Ziyauddin, Theodor Herzl'e bir mektup göndererek Yahudiler için başka bir yer bulmasını önerir (Tellioğlu, 2014: 198). Nitekim Herzl dâhil pek çok siyonist düşünür Arap problemi üzerinde fikir yürütmüştür. Bu minvalde siyonistler arasında bölgede Yahudilerin çoğunluk olduğu bir devlet kurmak için öncelikle bölgede Yahudi nüfusu arttırılmalı, bölge halkının bir devlet oluşumuna gitmesi engellenmeli ve son olarak ise bölge bir şekilde diğer halklardan temizlenmelidir (Morris, 1991). Nitekim Balfour Deklarasyonu'nun açıklanmasından sonraki gelişmelere bakıldığında bu durum daha net görülmektedir.

Balfour Deklarasyonu'nun 1917 tarihinde açıklanmasıyla siyonistler, İsrail'de bir Yahudi “yurdu” kurulması yönünde bir teminat elde etmiştir (Ediz, 2019). Siyonistler, Filistin'de bir Yahudi yurdu kurma sözü almalarına rağmen, bölgede henüz bir yurt/devlet kuracak düzeyde nüfusa sahip değildir. Bu nedenle Filistin'de İngiliz manda yönetimi kurulmadan önce 1919'da Paris Barış Konferansı'na katılan siyonistler, barış anlaşmasına Yahudiler lehine bazı maddeler eklemek istemiştir. 4 Ocak 1919'da Haim Weizmann Paris Barış Konferansı'na katıldığı sırada Balfour Deklarasyanu'nun anlaşmaya dâhil edilmesi, Filistin'e self-determinasyon hakkının verilmemesi, manda yönetiminin kurulması ve Yahudi göçünün sınırlandırılmaması şeklindeki isteklerini konferansa katılan devletlere kabul ettirmeyi başarmıştır (Balcı, 2010: 104-105). Wilson ilkeleri belirli bir bölgede devlet olmak için o bölgede çoğunluk oluşturabilecek miktarda nüfusu gerekli kılmaktaydı. Bu da Filistin'de bir Yahudi yurdu kurmanın ötesinde bir azınlığın çoğunluğa hükmetmesi ve Yahudi çoğunluğun nasıl sağlanacağı meselesiydi. İskit'in de işaret ettiği üzere "bu ancak bölgede devlet kurulmasının ertelenmesiyle mümkün olabilirdi. Bu da bölgede yeterli nüfus oluşana kadar Ingiliz mandası ve idaresi altında bir yönetim ile mümkün olabilirdi" (İskit, 2017: 239-242). Nitekim bölgede İngiliz idaresinin onaylanacağı anlaşma olan San Remo'da 
siyonistler hazır bulunacaktır. 25 Nisan 1920'de konferansın son günlerinde İngiliz Mandası kabul edilmiş ve 2 Kasım 1917'de ilan edilen deklarasyonu yürürlüğe koymakla yükümlü tutulmuştur. Balfour Deklarasyonu ilk defa bir uluslararası anlaşmada kayda geçmiştir. Böylelikle Yahudiler bölgede çoğunluğu sağlayana kadar bölgede bir devletin özellikle de Filistin Devleti'nin kurulmasının önü alınmıştır (Kasalak ve Deveci, 2017: 298-306; Ediz, 2015:141-176).

Bu tarihten itibaren bölgede demografik olarak çoğunluğu elde etmek amacıyla Avrupa'dan çok sayıda Yahudi bölgeye göç et(tiril)miştir. Filistin'de 1882'de 22 bin olan Yahudi nüfusu 1914'te 100 bine çıkmıştır. 1922 tarihli Britanya nüfus sayımlarına göre \% 88 Arap, \% 11 Yahudi şeklinde bir dağılım mevcuttur. 1931'de toplam 1.035.821 olan Filistin nüfusunun \% 82'si Arap \% 17'si Yahudi'dir. Bu ise İngiliz mandası dönemi politikaları nedeniyle Yahudi göçündeki yoğunluktan kaynaklıdır. 1948 savaşı sonrasında demografik dağılım, \% 80 Yahudi, \% 20 Arap şeklinde keskin bir değişim geçirmiştir (Al-Rimmawi ve Zeidan, 2013: 215-216). 1948'deki demografik dağılım ise 1948 Arap-İsrail savaşı sonucunda ìsrail Devleti'nin kurulmasıyla hâkimiyet kurduğu bölgede Yahudi çoğunluğu elde etmek için büyük bir Filistinli kitleyi yerlerinden etmekle elde edebilmiştir. Nitekim siyonistlerin Filistin'i bir Yahudi yurduna çevirmek istedikleri açıktır, bu minvalde pek çok çözüm ileri sürülmüştür. İlk olarak bölgeye çok sayıda Yahudi göç et(tiril)miş, fakat bu yeterli olmamıştır. Íkinci çözüm, yerleşik bir azınlığın yerli çoğunluğa hükmettiği ırk ayrımına dayanan bir devletin kurulması idi. Bu da "Avrupa değerlerini benimseyen" siyonistler için en azından ilk dönemlerde uygulanması zor bir çözümdü. Üçüncü çözüm ise taksimde yatmaktaydı. Göçler sonucunda bölgede çoğunluğu elde edemeyeceklerini anlayan siyonistler 1930'dan itibaren en azından bölgenin bir kısmında devlet kurmayı hedeflemiştir. 1947 BM taksim planı bu düşünceye uygun olmasına rağmen yine de önemli bir Arap nüfusu problemi bulunmaktaydı. Siyonistlerin nüfus sorununa en açık ve mantıklı çözüm Morris'in belirttiği üzere nakilde yatmaktaydı: "Arapların tamamını ya da çoğunu gelecekteki topraklarından taşımak ya da nakletmek suretiyle homojen bir Yahudi devlet en azından ezici bir Yahudi çoğunluğun olduğu bir nüfusla kurulabilirdi. Esasen 1948'de gerçekleşen budur" (Morris, 2012: 70-71; Morris, 1991: 42). Aslında bölge yerlilerinin transfer fikri Yahudi devletinin Yahudi karakterini sağlama noktasında siyonistler tarafından hep gerekli görülmüştür. Nitekim 12 Haziran 1895'te Theodor Herzl günlüğüne şu ifadeleri kaydetmiştir: "Usul usul istimlâk etmeliyiz... kendi ülkemizde onları ișten yoksun bırakırken, geçmiş ülkelerinde onlara iş sağlayarak heveslendireceğiz... hem istimlak süreci hem de yoksulların (yerlilerin) ihracı, ihtiyatlı ve temkinli bir şekilde yürütülmelidir" (Herzl, 1960: 88; Dikmen, 2019: 10-11).

\section{Arap Nüfus Problemi}

İsrail Devleti'nin bir Yahudi Devleti olabilmesi için girişilen demografik mücadele, 1948'den günümüze kadar büyük oranda Yahudi göçünü teşvikle 
yürütülmüştür. Yahudi göçünü teşvik etmenin yanında İsrail, kuruluşundan itibaren Yahudi karakterini korumak için sürgün, yerinden etme, Filistinlilerin yaşam alanlarını daraltma gibi politikalarla bölgeyi Arapsızlaştırma çabasında olmuştur. (Pappé, 2006: 6-20; Morris, 2004; Davis, 2016; White, 2017). İsrail yakın döneme kadar bu tarz politikalar sayesinde devletin Yahudi karakterli dengesini nispeten korumayı başarmıştır. Nitekim İsrail'deki Afrikalı göçmenlerin sınır dışı edilmesine dair Başbakan Benyamin Netanyahu, "bugün 38 bin yarın 150 bin, daha sonra 1,5 milyona çıkarlar" açıklamasını yaparak devletin Yahudi çoğunluğunu korumak için nüfus dengesinin Yahudiler lehine gözetilmesinin önemine işaret etmiștir (Haaretz, March 20, 2018). Aynı şekilde bazı muhafazakâr kesimler Afrikalı mültecilerin İsrail'in temel özelliği olan Yahudi karakterini ve demografisini değiştirdiğini belirterek bu mültecilerin sınır dışı edilmesine destek vermiştir. İsrail Afrika'dan alabileceği nüfus ile Filistin nüfusunu dengeleme şansına sahipken bu seçeneği tercih etmemektedir. Çünkü İsrail’de toprağa yönelik "ırk" temelli ve ideolojik bir düşünce hâkimdir. Yahudilere özgü "ülke topraklarının kurtuluşu” ideolojisi, İsrail'de Yahudi olmayan insanların sayısını en aza indirmeyi hedeflemektedir. Bu nedenle ülke topraklarında sadece Filistinliler değil Yahudi olmayan hiçbir varlığın, Yahudilere "vaat edilmiş" bu toprakları vatan edinmesine izin verilmesi mümkün görülmemektedir (Shahak, 2015: 27). Fakat Mart 2018'de açıklanan Filistin nüfus bilgileri, İsrail'i devletin Yahudi karakterini koruma noktasında oldukça zor bir sürecin beklediğini ortaya çıkarmıştır. Ayrıca "tek devletli" ve "iki devletli" barış planları açısından, bu nüfus probleminin İsrail'e büyük bir sıkıntı yaratacağı kanaatini oluşturmaktadır.

İsrail ordusu, 26 Mart 2018 tarihinde Knesset'e sunduğu bir brifingte, Akdeniz ve Ürdün nehri arasında yaşayan Arap nüfusunun yakın gelecekte Yahudi nüfusundan daha fazla olacağını ifade etmiştir. İsrail Sivil İdare Başkan Yardımcısı Albay Haim Mendes, 2 milyonu Gazze'de 3 milyonu Batı Şeria'da olmak üzere bölgede toplam 5 milyon Filistinlinin yaşadığını belirtmiştir (Haaretz, March 26, 2018; Gharabli, 2018). Bunun yanında bu rakamlara 1.5 milyonu aşan İsrail vatandaşı Arap ve 320 bin civarında Doğu Kudüs'te yaşayan Filistinli Arap eklendiğinde, Arap nüfusunun Yahudi nüfusuna yaklaştığı ve kısa bir süre içerisinde geçeceği iddiası ortaya atılmıştır. Nitekim yakın geçmişe bakıldığında bölgede Filistinlilerin nüfusunda önemli bir artış olduğu görülmektedir: 1997 tarihinde Batı Şeria ve Gazze'deki Filistinli nüfusu 2.895.685 iken 2017 yılı verilerine göre ise 4.780.978 (Gazze'de 1.890.291, Batı Şeria'da 2.881.687)'dir. İsrail Merkezi İstatistik Bürosu Eylül 2017 ve World Jewish Population, 2018 rakamlarına göre tarihi Filistin topraklarında, yani İsrail, Doğu Kudüs ve Batı Şeria'da, toplam 13.472.600 kişi yaşamaktadır (buna İsrail'deki yabancı işçiler dâhildir). Bunun 6.277.000'i Arap/Filistinli, 6.446.000'i ise Yahudilerden müteşekkildir. Bu verileri ortaya koyan Della Pergola'nın işaret ettiği üzere tarihsel Filistin'de belirgin bir Yahudi çoğunluktan bahsetmek mümkün değildir (Della Pergola, 2018: 33-34). Pek çok demografi uzmanı ve kurumu, Filistin'deki Arap ve Yahudi nüfusu arasındaki farkın 15-20 yıl, hatta daha kısa bir zamanda 
kapanacağını öngörmektedir. Nitekim Filistin demografisi üzerine yapılan bir çalışmada Filistinlilerin nüfusunun kısa bir süre içerisinde Yahudi nüfusunu geçeceğini ortaya çıkarmıştır. Oransal olarak 1922-2100 arasındaki demografik değişiklik göz önüne alındığında İsrail açısından Filistin nüfus artışının "tehlikesi” daha net görülmektedir. 1922 yılında İngiliz manda yönetiminin yaptığı nüfus sayımına göre Arap nüfusu toplam nüfusun \%88'i iken, Yahudi nüfusu \%11 civarındadır. 1949 yılından sonra yoğun Yahudi göçü ve Filistinlilerin "baskı ve katliamlar" ile yerlerinden edilmesi sonucu demografik durum, \%80 Yahudi, \%20 Arap şeklinde Yahudiler lehine değişmiştir. 1949'dan itibaren İsrail'e çevre ülkeler ve Avrupa'dan yoğun Yahudi göçüne rağmen 2010 verilerine göre demografik durum \%47 Arap, \%53 Yahudi şeklindedir. 2025 yılında demografik durumun \%53'e \%47 Arapların lehine değişmesi beklenmektedir:

\begin{tabular}{|c|c|c|c|c|}
\hline Milliyet & Arap & Yahudi & Diğer & Toplam \\
\hline 1945 & 1.196 & 554 & 1 & 1.764 \\
\hline$\%$ & 68 & 31 & - & 100 \\
\hline 1949 & 150 & 600 & - & 750 \\
\hline$\%$ & 20 & 80 & - & 100 \\
\hline 2010 & 5.378 & 6.000 & - & 11.378 \\
\hline$\%$ & 47 & 53 & - & 100 \\
\hline $\mathbf{2 0 2 5}$ & 8.360 & 7230 & - & 15.590 \\
\hline$\%$ & 53 & 47 & - & 100 \\
\hline $\mathbf{2 0 5 0}$ & 9.989 & 11.114 & - & 21.103 \\
\hline$\%$ & 47 & 53 & - & 100 \\
\hline $\mathbf{2 1 0 0}$ & 9.833 & 14.932 & - & 24.765 \\
\hline$\%$ & 40 & 60 & - & 100 \\
\hline
\end{tabular}

Tablo 1: Filistin Nüfusu (1922-2010 arası resmi-2025-2100 tahmini) (Al-Rimmawi ve Zeidan, 2013: 215-216).

Nitekim İsrail ve Filistinlilerin nüfus artış hızına bakıldığında aradaki demografik farkın yakın gelecekte kapanacağı tahmin edilmektedir. Filistin Merkezi İstatistik Bürosu'nun "Palestine in Figures 2016" başlıklı raporu, Filistinlilerin yıllık nüfus artış hızını Gazze'de 3.3, Batı Şeria'da 2.5 ve ortalama 2.8 olarak vermektedir (Palestinian Central Bureau of Statistics: Palestine in Figures 2016, March 2017: 13). İsrail'in nüfus artış hızı ise 2006-2015 yıları arasında 1.8 civarında sabit bir hızdadır (Arutz Sheva, May 22, 2017). Fakat bu orana İsrail 
vatandaşı Filistinliler de dâhildir. Nitekim İsrail Ynetnew haber sitesi 30 Ağustos 2017 tarihinde yaptığı bir haberde, İsrail vatandaşı Arapların nüfus artış hızının Yahudiler ve diğer azınlıklardan daha fazla olduğuna işaret etmiştir. 1.5 milyondan daha fazla nüfusu ile ülkenin yaklaşık \%20'sini oluşturan Filistinlilerin 2.4 ile en yüksek nüfus artış hızına sahip olduğunu belirtmiştir (Ynetnew, August 30, 2017).

İsrail Devleti'nin kalbi ve ana öğesini oluşturan Yahudi göçünün 1990'da sonra büyük bir düşüş içerisinde olduğu gözlenmektedir. Göç (olim) İsrail’i yaratan olgudur. Bu göçler İsrail'i oluşturmakla kalmamış, İsrail'in kültürel, sosyal, siyasi ve ekonomik hayatını şekillendirmiştir. 1948-51 arasında devletin kuruluşunu takip eden üç yıl içinde 688 bin yeni göçmen İsrail'e göç etmiştir. Bununla birlikte çevre ülkelerden -Irak, Yemen, Kuzey Afrika- Yahudiler İsrail'e çeşitli operasyonlar ile getirilmiştir. 1980-1990 yılları arasında Rusya'dan yaklaşık 1 milyon Yahudi göçmenin İsrail'e ulaşmasıyla ülke önemli düzeyde nüfus desteği almıştır. Bununla birlikte İsrail'e 1984-2008 yılları arasında yaklaşık 150 bin Etiyopyalı Yahudi göç -demografik denge adına- et(tiril)miştir (Immell, 2010: 6-7).

\begin{tabular}{|l|l|l|l|l|}
\hline Yıllar & $\begin{array}{l}\text { Dönemin } \\
\text { Yahudi } \\
\text { Nüfusu }\end{array}$ & $\begin{array}{l}\text { Yahudi } \\
\text { Göçmen } \\
\text { Sayısı }\end{array}$ & $\begin{array}{l}\text { Yıllık } \\
\text { Göçmen } \\
\text { Sayısı }\end{array}$ & $\begin{array}{l}\text { Sadece göçten } \\
\text { kaynaklanan } \\
\text { yıllık nüfus } \\
\text { artış hızı }\end{array}$ \\
\hline $\mathbf{1 8 8 2 - 1 9 4 8}$ & $\mathbf{2 4 , 0 0 0}$ & 543,857 & 8.293 & 4.9 \\
\hline $\mathbf{1 9 4 8 - 1 9 5 1}$ & 649,500 & 687,624 & 194,244 & 22.6 \\
\hline $\mathbf{1 9 5 2 - 1 9 6 6}$ & $1,404,400$ & 587,472 & 39,165 & 2.4 \\
\hline $\mathbf{1 9 6 7 - 1 9 8 9}$ & $1,344,900$ & 558,909 & 24,300 & 0.9 \\
\hline $\mathbf{1 9 9 0 - 1 9 9 8}$ & $3,717,100$ & 879,486 & 97,721 & 2.4 \\
\hline
\end{tabular}

Tablo 2: $1982-1998$ yılları arasında Yahudi nüfusu, göçmen sayısı ve artış oranı. ${ }^{4}$

4 Neuman, 1999: 57; Yıllara göre nüfus bilgileri için ayrıca bkz. Statistical Abstract of Israel (Jerusalem: Government of Israel, Central Bureau of Statistics, 1992) naklen Peretz ve Doron, 1997: 48. 


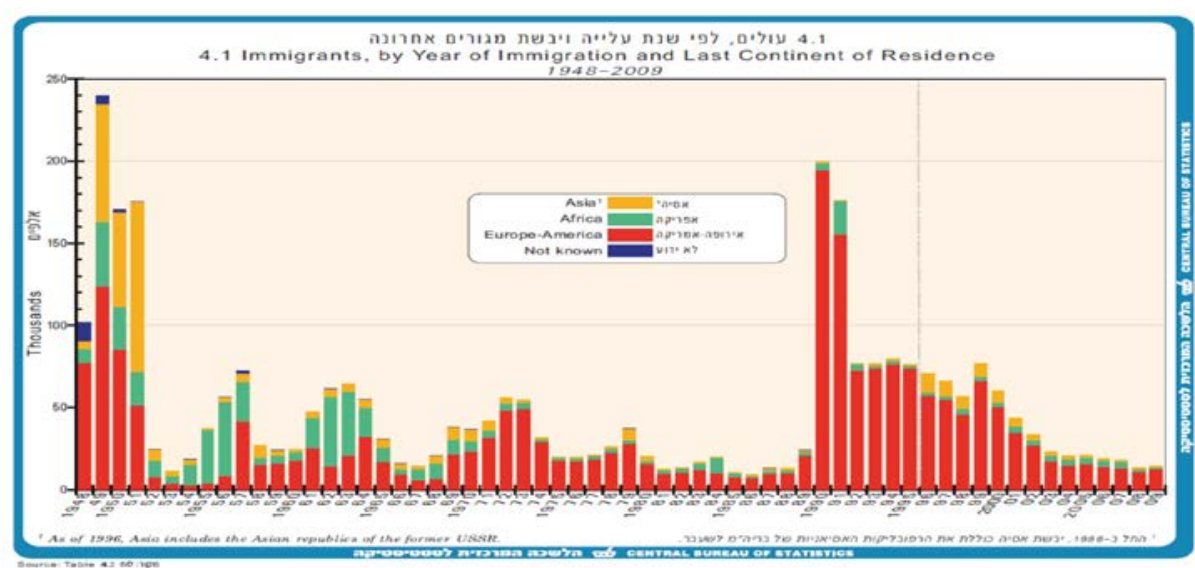

Grafik 1: 1948-2009 yılları arasında İsrail'e göç eden göçmen grafiği. (Lustick, 2011: 38).

Tablo 2 ve Grafik 1'e bakıldığında İsrail, ülkenin demografik dengesini Yahudiler lehine dengelemek için dünyanın farklı yerlerinden Yahudileri ülkeye taşımıştır. Ayrıca yine Grafik 1'e bakıldığında Yahudi göçünün 1990'dan sonra düşüşe geçtiği görülmektedir. 1990'lar boyunca Sovyetler Birliği ülkelerinden 1 milyona yakın Yahudi göç etmesine rağmen, 1988'de bölgede \%81,4 olan Yahudi oranı, 1998'de \%79,2'e düşmüştür (Haaretz, October 4, 2010). Nitekim Amerika hariç dünyanın diğer ülkelerinde Yahudi göçmen rezervinin önemli düzeyde azalmasıyla birlikte İsrail'i oluşturan ve besleyen göçmen unsuru gücünü kaybetmeye başlamıştır. ${ }^{5}$

1980'lerin ortalarından itibaren İsrail'de nüfus problemi çok daha akut oldu. Bu, Körfez'deki Filistinli göçmen sayısındaki ciddi düşüşten kaynaklanmaktaydı. İsrail'in uzun süreli Yahudi karakterini koruma vizyonu tehlikedeydi. Bunun üzerine İsrail aşırı sağı Arap nüfusunun transferi fikrini ortaya atmış, fakat büyük destek görmemiştir. Shapira'nın işaret ettiği üzere bu İsrail için iki seçenek doğurmaktaydı. Illk olarak tek devlet çatısı altında bütün Arapları İsrail vatandaşlığı vermek, bu da 20 yıl içinde Yahudilerin azınlığa düşmesine neden olurdu. İkinci seçenek ise iki devletli sistemdir (Shapira, 2012: 418). Nüfus probleminin İsrail'i ittiği bu iki seçenek gündemi işgal etmesine rağmen 1990'larda İsrail'e göç eden 1 milyona yakın Sovyet göçmeni (Al-Haj: 2004) ve İsrail'in 2005'te Gazze'den çekilmesiyle (Deutche Welle, Ağustos 17,

5 İsrail'in halihazırda diaspora Yahudileri özellikle Amerikan Yahudilerinin İsrail'e göç trendi istenilen düzeyde değildir. ABD'de şu anda yaklaşı 6 milyon Yahudi yaşamaktadır. İsrail kurulduğundan itibaren Amerika'dan i̇srail'e göç eden Yahudi sayısı 100 ile 150 bin arasında değişmektedir. Nitekim Yahudiler için başlangıçtan itibaren Amerika İsrail'e oranla daha çekicidir. Nitekim göç eden birçok Amerikalı Yahudi'nin geri göç ettiği bilinmektedir. Bkz. Tal, 2016: 69, 76. 2017'de İsrail nüfusu 6.558.000 iken 2018'de \%1.74'lük bir artışla 6.446.00o'e yükselmiştir. Diasporadaki Yahudi nüfusu ise 8.061.500'den 8.047.900' düşmüştür. Bu düşüşün sebebi israil'e göçten kaynaklıdır. İsrail nüfus artışı büyük oranda doğal yollarla gerçekleşirken, göç önemli bir nüfus kaynağını ihtiva etmektedir. Bu noktada İsrail diasporadan kaynaklı göçü bir nebze artırmayı başarabilirse nispeten demografik dengeyi koruyabilir (Della Pergola, 2018: 12; Della Pargola, 2011). 
2005) bir süre çözülmüş gibi durdu. Fakat son nüfus verilerinin gösterdiği üzere bölgede Yahudi olmayan nüfusun hızlı artışı, nüfus problemini yeniden gündeme getirmiştir (Lustick 2013: 36). Nitekim Netanyahu'nun 2009'daki “hükümet, göçmenlik ve göçmenlerin özümseme konusunu öncelikle listesinin en üstüne yerleştirecek ve dünyanın tüm ülkelerinden (Yahudi) göçü artırmak için güçlü bir şekilde çalışacaktır” (Lustick, 2013: 34) açıklaması, nüfus probleminin yeniden ortaya çıktığını göstermektedir.

İsrail'deki muhafazakâr kesim, İsrail ordusu tarafından açıklanan demografik rakamların hatalı olduğunu ve Batı Şeria'daki demografik ve zamansal avantajın Yahudilerin lehine işlediğini iddia etmektedir. Belirtilen görüşlerde İsrail muhafazakâr kesiminin bu tutumu, Batı Şeria'daki işgalleri sürdürmek hatta Batı Şeria'yı ilhak etmek için var olan engelleri kaldırma ya da görmezden gelme çabası olduğu yönündedir. Buna karşın İsrailli milletvekili Tzipi Livni (Zionist Union) twitter üzerinden yaptığı paylaşımda, bu demografik verilerin İsrail Devleti için bir uyarı olduğunu belirterek “eğer İsrail, Batı Şeria’yı ilhak etme hayalinden uyanmazsa Yahudi çoğunluğunu ve 'karakterini' kaybedecektir” ifadesini kullanmıştır. Yine twitter üzerinde Birleşik Arap Listesi lideri Ayman Odeh ise “Akdeniz'den Ürdün nehrine kadar Arap ve Yahudi nüfusu eşit ve bu yeni değil. Bu da bize yol haritasını açık ediyor: Ya 1967 sınırlarında iki devletli çözüm ya Apartheid (ırk temelinde ayrımcılık) tek devlet ya da herkesin eşit oy hakkının olduğu demokratik bir devlet. Başka seçenek yok" şeklinde açıklama yapmıştır (Haaretz, March 26, 2018; The Times of Israel, March 28, 2018; Wafa, March 28, 2018).

Filistinlilerin nüfus istatistiklerinin açıklanmasının ardından, İsrail’in Yahudi çoğunluğu/karakterinin tehlikede olduğu tartışması üzerine, muhafazakâr kesimden Batı Şeria'da yerleşimleri organize eden Yeşa Konseyi CEO'su Yigal Dilmoni, Filistin nüfusunun abartıldığını belirtmiştir. Yine Kanal 10’a verdiği bir röportajda Dilmoni, "Filistinlilerin sayısına bakılmadan Kutsal Toprakları yönetmek 'çoğunluk olsun veya olmasın' tamamen bizim (Yahudiler) hakkımızdır" ve "Ben Gurion devleti kurduğunda 2 milyon Arap'a karşı 600 bin Yahudi vardı" ifadelerini kullanmıştır (Burston, 2018). Filistinlerin nüfusunun bu derece artması öncelikle yerleşimcilere sıkıntı yaratacağı için Dilmoni gibi muhafazakâr kişilerin bu şekilde cevap vermesi normal karşılanmaktadır. Fakat burada Dilmoni'nin nüfus verilerini reddetmesinden öte "Yahudilerin çoğunluk veya değil, İsrail'de hükmedecek taraf olacağı” vurgusudur. Bugüne kadar en azından Yahudi çoğunluğuna güvenerek devletin Yahudi karakterine atıf yapılmaktaydı. Fakat artık demografik olarak farkın ortadan kalkmış olması, Yahudilerin yönetim üzerindeki hak iddiasının ve devletin Yahudi karakterinin daha fazla güç ile işleyeceğine işaret etmektedir. Bu düşünce İsrail aşırı sağının önemli bir figürü olan Rabbi Meir Kahane gibi düşünürlerden miras alınmıştır. Nitekim Kahane, Arapları “köpek” veya "pire gibi çoğalan” olarak vasıflandırarak devletin güç ile elde ettiğini Arapların nüfus ile alt üst edeceğini belirterek her 
durumda taviz verilmeden Araplara karşı güç ve sürgün fikrini savunmuştur (Kahane, 2012: 42, 63; Kahane, 1981).

İsrail'de aşırı sağ ve nüfus arasındaki önemli bir bağlantı ise kürtaj meselesidir. İsrail'de önemli bir problem olan kürtaj meselesinin aşırı sağın dini nedenlerle engellemeye çalıştığı genel kanıdır. Fakat kürtajın İsrail'de sorun olmasının en büyük sebebi dini olmaktan çok nüfusla ilgilidir. Amira Gelblum'un savaşa karşı verdiği mücadeleyi anlatan bir röportajda İsrail'deki aşırı sağ için Yahudi kadınların kürtaj yapması Auschwitz gibi bir olumsuzluğu ifade etiğini belirtir. Ayrıca yetkililerin Arap kadınları kürtaj ve doğum kontrol konusunda olabildiğince teşvik ve kolaylık sağlanması yönünde çağrıda bulunduğuna işaret etmektedir. Bu minvalde İsrail'de ne zaman kürtaj hakkı istemiyle bir gösteri kampanyası başlatılsa İsrailli yetkililer tarafından Yahudi göçünün yeteri düzeyde gerçekleşmemesi dolayısıyla Yahudi nüfus oranını düşürecek bu tür eylemlerin hatalı ve kaçınılması gerektiğine dair açıklamalar yapılmaktadır (Bunzl, 1988: 40).

\section{İsrail'in Yahudi Karakteri Nasıl Korunur?}

İsrail'in Yahudi karakterini veya çoğunluğunu koruma konusunda İsrail'deki politik gruplar nispeten aynı fikirdedir. Fakat bu çoğunluğun nasıl sağlanması gerektiği konusunda büyük bir ayrılık mevcuttur. Öncelikle iki devletli barış planı önerisi ele alındığında İsrail'deki sol ve liberal kesimler, bunun İsrail'in Yahudi çoğunluğunu koruma konusunda en iyi çözüm olacağı kanaatindedir. Fakat İsrail muhafazakâr ve milliyetçileri -özellikle aşırı sağ- açısından 1967 sınırlarında iki devletli bir çözümü kabul etmek hem Batı Şeria ve Doğu Kudüs üzerindeki "haklarının” hem de Yahudi yerleşimlerin durumunu tehlikeye atacağı gerekçesiyle mümkün görünmemektedir. Özellikle İsrail’in olası bir anlaşma sonucu buradaki yerleşimleri çekme mevzusunun i̇srail'de var olan ayrılıkları derinleştireceği hatta bir iç savaş çıkabileceği iddia edilmektedir. Nitekim ABD'nin İsrail Büyükelçisi David Friedman, Kudüs'te Yahudi Amerikalı kanaat önderlerine, "Batı Şeria'dan yerleşimlerin tahliyesi iç savaşa sebep olabilir" açıklamasını yapmıştır. Ayrıca İsrail ordusu içerisinde, Akdeniz'den Ürdün nehrine kadar olan Büyük İsrail düşüncesine bağlı aşırı sağın artışına atıf yapılarak bu girişimin istenmeyen sonuçları olabileceğine işaret edilmiştir (The Jerusalem Post, February 20, 2018). Bu plan, İsrail'e Yahudi çoğunluğunu kazandırmasına rağmen "yeni siyonist" anlayışın ön gördüğü pek çok adımdan vazgeçme ve yeni sorunlar ile karşılaşma ihtimali doğurmaktadır.

Tek devletli barış planı ise özellikle demografik bağlamda çok daha sıkıntılı bir durum yaratmaktadır. Bu durumda İsrail ya ırkçı bir yönetim benimseyerek Filistinlilere zorba bir dayatmacılık uygulamaya devam edecek ya da Filistinlilere demokratik haklar sunacaktır. İkinci seçeneği sunduğu takdirde, nüfus artış oranı Yahudilerden fazla olan Filistinlilerin çoğunluğu elde etme ve yönetimi ele geçirme imkânına kavuşması ihtimal dâhilindedir. Bu da İsrail'in silahla ve zorla 
ele geçirdiği toprakları demokratik yollarla teslim etmesi anlamına gelmektedir. Aynı zamanda İsrail'de her kesim tarafından vurgulanan Yahudi çoğunluğu kaybetmek anlamına gelmektedir. Bununla birlikte tek devletli çözüm planında İsrail'in Filistinlilere ilave haklar vermeyi düşünmediğini belirtmek gerekiyor. Bu planın ırkçı versiyonunda, bütün topraklar İsrail'in hegemonyası altında, Filistinlilere istenilen ölçüde hak veya özgürlük sunulan ve istemeyen olursa kapı dışarı etme inisiyatifini elinde bulunduran bir “çözüm” olarak düşünülmektedir (Morris, 2009; Aydın, 2010; Balpınar, 2019: 424-425). Bu da Filistinliler için var olan koşulların devamı, muhtemelen daha sorunlu bir durum anlamı taşımaktadır.

İsrail açısından özellikle devletin Yahudi karakterine verdiği önem dolayısıyla oluşan problemleri tek ve iki devletli çözüp planları ile aşmak hâlihazırda mümkün gözükmemekte veya tercih edilmemektedir. Peki, İsrail demografik değişime nasıl cevap vermektedir? Bu aslında devletler demografik değişimlere nasıl cevap verir? sorusunda cevap bulmaktadır. Özellikle iki baskın etnik kimliğin hâkim olduğu devletler nüfus değişimlerine, askeri güç kullanma, vatandaşlığın yasal karakterini ve sınırları belirleme ve göçmen akınını etkin bir şekilde yönetmek şeklinde cevap verirler (Weiner ve Russell, 2001: 10). Birinci madde göçmen bazında ele alınmaktadır, ama askeri manada azınlıkları kontrol etmek için kullanmaktadır. ikinci madde ise çoğul uyruklukta bir etnik yapının oranının artışı sonucudur. Bu noktada devletlerin iki seçeneği bulunmaktadır. Birincisi, çoğul bir milliyet tanımı yapmak, ikincisi ise milli kimliği korumak için vatandaşlık kimliğini devletle özdeşleştirmek şeklinde homojenleştirmektir (Weiner ve Russell, 2001: 10). İsrail açısından olaya baktığımızda, Filistin nüfusundaki artışı kontrol etmek için askeri güç ile kontrol ve dışarıdan Yahudi göçünü teşvik etme veya Filistinli mültecilerin geri dönüşünü engelleme gibi önlemler tarihsel bir süreklilik taşımaktadır. Fakat İsrail için Filistin nüfusundaki artış karşısında devletin Yahudi karakterini koruma refleksi olarak iki yeni olgu dâhil olmuştur. Birincisi 2018'de ilan edilen Yahudi Ulus Devlet Yasası ile Yahudi vatandaşlık kimliğini devletle özdeşleştirmek şeklinde homojenleștirmektir. İkincisi ise ABD liderliğinde 2020'de ilan edilen Yüzyılın Anlaşması planıdır. Bu planın maddelerine bakıldığında İsrail'in aslında Batı Şeria'da geçirgen ve belirsiz olan Arap çoğunluğunun yaşadığı bölgelerden kendisini soyutlayarak ve sınırlarını keskinleştirerek Yahudi karakteri korumaya çalıştığı görülmektedir.

Öncelikli olarak 2018'de "Temel Kanun: İsrail Yahudilerin Ulus Devleti" isimli yasa ele alındığında, ulus tanımının dar anlamıyla veya sadece Yahudilere dayanarak tanımlanması ve Arapları ikinci sınıf vatandaş statüsüne düşürme gayreti, kimliksel bazda İsrail'in açık bir şekilde homojenleştirilme ve Yahudileştirilme çabasının tezahürüdür. Anayasal bir metne sahip olmayan İsrail bu yasa ile devletin politik ve toplumsal karakterini belirleyerek Yahudileştirmektedir. İsrail Bağımsızlık Bildirgesi'nde dinsel ve etnik referanslara bir vurgu bulunmakla birlikte Yahudi çoğunluğun vermiş olduğu özgüven, seküler ve kültürel Yahudiliği önemseyen kurucu elitler, bildirgede "vatandaşlık, din, etnik ve cinsiyet ayrımına tabi tutulmadan vatandaşlık ilkesini eşitlik etrafında 
kurgulamıştır” (Çınkara, 2020: 193). Bu nedenle Arapların vatandaşlık temsili nispeten tehdit olmaktan uzaktı. Fakat Filistin'deki demografik değişime paralel olarak İsrail siyasetinde güç kazanan sağ kanatta duran milliyetçi gruplar açısından artan Arap nüfusu, devletin Yahudi karakteri üzerinde baskı oluşturmakta ve bu baskının kontrolü gittikçe zorlaşmaktadır. Bu noktada bir ülkede politik ve ekonomik gücü olmayan nüfustaki hızı artış, var olan gücü ve etniklikle ilişkilendirilen ideolojik yapıyı tehdit eder. Bu minvalde var olan statükocu yapı, gücünü korumak adına gücü demografik etkenle paralel artan grupların önüne bazı engeller koymaya başlar. Böylelikle devlete hâkim olan grubun dominant kültür ve değerlerinin demografik değişim sonucu aşınma ihtimalini engellemeye çalışır (Saenz ve ark, 2015: 8). ${ }^{6}$ İsrail gibi anayasası olmayan bir ülkede bu yasa, anayasal bir statüdedir. Yani vatandaşlarla kurulacak ilişki, alt hukuki düzenlemeler ve idari işlemlerde bu kanun referans metni olacaktır. Bundan İsrail'de yaşayan iki milyona yakın Arap doğrudan etkilenmektedir (Çınkara, 2020: 198). Nitekim kanun maddelerine bakıldığında İsrail'deki geniş olan vatandaşlık temsilinin nasıl Yahudileştiği açık bir şekilde görülmektedir; İsrail Devleti Yahudi halkının ulus devletidir, İsrail Devleti'nde kendi kaderini tayin etme hakkı ulusal düzeyde Geri Dönüş Kanunu'na uygun olarak sadece Yahudilere mahsus kılınmıştır, ibranice devletin resmi dilidir, Arapça resmi dil hüviyetini kaybederek bir kanunla düzenlemek üzere özel statüye sahip olmuştur, devlet Yahudi yerleşimleri teşvik, destek ve korumakla yükümlüdür; ulusal marş Hatikva'dır; bayrak İsrail bayrağıdır; Yom Hatzmaut milli bayramdır; İbrani takvimi devletin resmi takvimidir; Şabat ve dini tatiller resmi Yahudi tatilleridir vs. (Basic Law: Israel-The National State of the Jewish People) Çınkara'nın belirttiği üzere vatandaşlığı sadece Yahudilerle özdeşleştirilmesi, İsrail'de vatandaş olmayı anlamsızlaştırmakta... devletin karakterinin etnokrasi ve aşiretçiliğe doğru evrildiğini göstermektedir (Çınkara, 2020:198; Ayrıca bkz. Kimmerling, 2001).

İsrail'in kendisini sınırlandırma veya Arap tehdidinden uzaklaştırmasının bir diğer yolu ise "Yüzyılın Anlaşması" ile belirginleşmiştir. İki devletli plana nispeten yakın olmasına rağmen İsrail’i Filistinlilerden daha fazla soyutlayan bir yapıya sahiptir. Anlașma maddelerinin yayımlanmasından sonra yapılan yorumlar, bu anlaşmanın “Filistin’i buharlaştırma” projesi olduğu şeklindedir (Tomar, 2019;

\footnotetext{
6 Son yıllarda küreselleşmenin zayıflaması ile birlikte dünya genelinde ulus-devlet davranışlarının yeniden güçlenmeye başladığı görülmektedir. Konu üzerine var olan tartışmaların büyük çoğunluğu devletlerin yeniden ulus-devlet davranışları göstermesini küreselleşmenin zayıflamasına bağlamaktadır. Fakat Hindistan, Rusya ve İsrail örneklerine bakıldığında farklı bir olgunun buna sebep olduğu görülmektedir. Bu noktada demografik faktörünün yeniden ulus-devletleşmede önemli bir rol oynadığı görülmektedir. Özellikle 2018'de önce İsrail'in ulus-devlet yasası, daha sonra 2019'da Hindistan'da benzer kanun ve 2020'de Rusya'daki kanuna bakıldığında, üç kanunda da ülkede çoğunluk olan daha doğrusu ülkenin karakterinde baskın olan etnik yapıların ülke üzerindeki kimliksel önemine vurgu yapmaktadır. Üç kanunda da ön plana çıkan ülkenin kimliğinin Yahudi, Rus ve Hint olarak vurgulanması, dil noktasında vurgular bu ülkelerin, baskın olan etnik yapının tehdit hissettiği ve bunu tekrardan vurgulamak, kanun yoluyla garanti altına almaya çalıştığıdır. Belirtilen ülkelerin bu davranışının altında Müslüman nüfusunun hızla büyümesi önemli bir rol oynamaktadır. Temel iddia baskın olan etnik yapılar, demografik tehlikenin oluşturduğu durumdan kanun yoluyla yeniden ulus-devletleşmeye gitmekle gözetmeye çalıștı̆̆ıdır. Rusya ve Hindistan'daki yasalar için bkz. Çalışkan, 2020; BBC, Aralık 11, 2019.
} 
Kurşun, 2019; Hawwash, 2019; Cook, 2019; Oruç, 2019). Bu görüşe büyük ölçüde katılmakla birlikte anlaşmanın ikinci bir amacı ise İsrail’i Filistinlilerden soyutlamaktır. Yukarıda belirtildiği üzere İsrail, Filistinlilerle olan ilişkilerinde demografik denge konusuna büyük önem vermektedir. Bölgedeki demografik dengede İsrail aleyhine meydana gelen bir değişiklik, İsraillilerin tehdit duygusunu artırarak İsrail’i şu anki belirsiz ve geçirgen sınırlardan uzaklaştırarak, net sınırlar oluşturmaya teşvik ediyor. Kartil ve Schnell'in belirttiği üzere kimliğin veya statükonun (devletin Yahudi karakteri) istikrarı sınırların belirli olmasına bağlıdır. Bu nedenle "israil'de 2000 yılından itibaren demografik değişiklik kaynaklı tehdit duygusunu azaltmak için toprak imtiyazı çözümüne ve Filistin nüfusu üzerindeki kontrolü bırakmaya çağıran duruşa artan bir destek var" (Kartil ve Schnell, 2018, 3. ve 20. Madde).

ABD tarafından Golan tepelerini İsrail tarafından ilhakının tanınması, Kudüs'ün İsrail'in başkenti olarak kabulü ve $A B D$ büyükelçiliğinin Kudüs'e taşınması; Batı Şeria'nın ilhakına yönelik yapılan tartışmalara bakıldığında İsrail'in devletin sınırlarını belli ölçülerde çizerek kendisini Filistinlilerden soyutlamak istediği görülmektedir. Özellikle anlaşma maddelerinde Filistinli mültecilere çok az yer vermesi, demografik olarak Batı Şeria'nın tamamının kontrolünün mümkün olmayacağının farkında olarak sadece ilhakı yerleşimler ile sınırlandırma çabası (Peace to Prosperity, White House, 2020; Tuygan 2020), İsrail'in artık kontrol etmekte zorlandığı nüfus probleminin devletin sınırlarını belli ölçülerde belirleyerek kendisini Filistinlilerden soyutlama şeklinde çözmeye çalıştığı kanaatini oluşturmaktadır.

Özgür Dikmen'in de işaret ettiği üzere İsrail siyasetçilerinin son dönemdeki en önemli gündemlerinden bir tanesi demografik yapı meselesidir. Mart 2018'de Haaretz gazetesine verdiği bir röportajda, Eski İsrail Genelkurmay Başkanı Gabi Eisenkot, İsrail sınırlarında güvenlik problemlerinin arttığını, fakat problem yaratan/yaratacak en büyük kıpırdamanın Filistinliler arasında olduğunu belirterek bu problemle başa çıkmanın zor olacağını ifade etmiştir (Haaretz, March 28, 2018). Devletin güvenliğini ve varlığını koruma noktasında en önemli maddelerden biri olması hasebiyle, "devletin kendisini teritoryal olarak kısıtlaması ve nüfussal açıdan kontrol edebileceği topraklar üzerinde siyaset yürütmeye itmektedir. Golan ve Kudüs'ü ilhak edebilirsiniz ama Gazze veya Batı Şeria gibi son dönemlerde tartışmalara konu olan Arap çoğunluklu ve ilhak edildiğinde ciddi demografik ve güvenlik problemleri yaratmaktadır" (Dikmen, 2019: 5). Bu nedenle İsrail'in kazanımlarını tehlikeye sokma ihtimali bulunan bütünü elde etmeye kalkışmaktan öte bütün içerisinde kontrol edebileceği sınırları elde tutmaya odaklanacaktır. Bu minvalde yine Dikmen'in işaret ettiği üzere “homojen bir Yahudi toplumuna evirilmesi için yine Yahudi milliyetçi bir yapıya dayanmak zorunda kalmaktadır. Nitekim son dönemde Netanyahu ile artan milliyetçi ve dindar yükseliş, homojenliği yakalamaya yöneliktir veya bunun bir sonucudur" (Dikmen, 2019: 5). 


\section{Sonuç}

İsrail Devleti, iki bin yıllık başka dinî ve etnik grupların hâkimiyetinde azınlık olarak yaşamanın getirmiş olduğu yükten kurtulma düşüncesinin ürünüdür. Bu noktada Yahudiler için azınlık olmak en büyük zayıflıklardandır. Azınlık olma yani zayıf olma durumundan kurtulmak için düşünsel olarak geliştirilen ve 1948'de hayata geçen İsrail Devleti'nin Yahudi karakterde, demografik anlamda Yahudi çoğunluklu bir devlet olması, devletin temel taşlarından birini oluşturmaktadır. Bununla birlikte devletin ulusal güvenliği ile doğrudan bağlantılıdır. Bu minvalde, siyonizmin ilk dönemlerinden itibaren bir sorun olan nüfus, bugün İsrail için daha akut bir problem haline gelmiştir. 1861-1865 yılları arasında Amerikan İç Savaşına neden olan köleliğin ABD için büyük bir probleme gebe olduğunu Thomas Jefferson 1819'da şu sözlerle ifade etmişti; Gecenin derinliğinde çınlayan bir yangın çanı gibi. İsrail için ise nüfus problemi özellikle Arap nüfusu düşünüldüğünde Jefferson'un işaret ettiği minvalde bir yangın çanıdır. ABD tarihinde kölelik sorunun çözümü ve haklarının iadesi büyük toplumsal ve siyasal problemlere neden olmuştur. Aynı şekilde nüfus trendinin İsrail ulusal güvenliği ve üzerinde temellendiği ulusal ideoloji aleyhine bir değişim geçirmesi nedeniyle ciddi toplumsal ve siyasal krizlere gebedir. Özellikle nüfus problemine çözüm olarak sunulabilecek mevcut tek devletli ve iki devletli planların çözüm noktasında işler ve kabul edilebilir olmaması krizi derinleştirmektedir.

Hâlihazırdaki nüfus verilerine göre tarihi Filistin bölgesinde şu anda çoğunluğu Yahudiler oluşturmasına rağmen yakın gelecekte bu olgunun Yahudiler aleyhine değișeceği tahmin edilmektedir. Bu Siyonizm'in tarihsel anlamda üzerinde temellendiği çoğunluğunun Yahudilerden oluştuğu Yahudi karakterli bir devlet fikrini tehdit etmektedir. Bu minvalde İsrailli yetkililer yeni göç rezervleri veya Yahudi nüfusunu artıracak yeni önlemler almadıkları durumda yeniden azınlık olma korkusunun hortlayacağının farkındadır. İsrailli yetkililerin bu noktada nasıl önlemler alacakları belirsizlik taşımakla birlikte yeniden baş gösteren nüfus probleminin İsrail’i bazı noktalara ittiği söylenebilir. Metin içerisinde tartışıldığı üzere İsrail açısından şu anda tek veya iki devletli çözüme ulaşma noktasında çözülmemiş ve çözülmesi yıllar alabilecek engeller bulunmaktadır. Bu iki planın işler olmaması nedeniyle İsrail farklı bir çözüm yoluna girmiştir. Bu ise vatandaşlığın yasal karakterini ve sınırları belirleme politikasıdır. Bu politika kendisini nispeten "Yüzyılın Anlaşması" ve "Yahudi Ulus Devlet Yasası" ile göstermiştir. İki baskın etnik yapı üzerine temellenmiş veya etnik çatışmanın olduğu İsrail, nüfus değişimine öncelikle vatandaşlığın yasal karakterini Yahudiler lehine (Yahudi Ulus Devlet Yasası) belirginleştirmekle cevap vermiştir. Bunun yanında mevcut korunmaya çalışılan kimlik ve statükonun (devletin Yahudi karakteri) istikrarı ise devletin sınırlarının belirgin olmasına bağlıdır. Bu noktanın farkında olan İsrailli yetkililer Yüzyılın Anlaşması'nı devreye sokmuşlardır. Böylelikle homojen bir Yahudi toplumunu elde etmek veya olabildiğince korumak için İsrail, artık kontrol etmekte zorlandığı nüfus problemini devletin sınırlarını belli ölçülerde belirleyerek kendisini Filistinlilerden 
soyutlayarak çözme eğilimi göstermektedir. Aynı şekilde Yahudi Ulus Devlet yasası ile İsrail, milli kimliği korumak için vatandaşlık kimliğini devletle özdeşleştirmek şeklinde homojenleştirmektir. Böylelikle hem fiziki hem de kimliksel olarak kendisini Filistinlilerden (Arap) soyutlamaktadır. İsrail'in kendisini Filistinlilerden belli ölçülerde soyutlayarak homojen bir Yahudi toplumuna evirme çabası, İsrail siyasetini Yahudi milliyetçi ve dindar bir yapıya dayanma mecburiyetinde bırakmaktadır. Bu noktada, ortaya konulan çaba ve politikanın İsrail lehine olumlu bir sonuç üretip üretmeyeceği nüfus dengesine ve İsrail hükümetlerinin politikalarına bağlı olacaktır.

\section{Kaynakça}

"Basic Law: Israel-The National State of the Jewish People", https://knesset.gov.il/laws/special/eng/BasicLawNationState.pdf adresinden alındı

"Central Bureau of Statistics reports Muslim growth rate stil highest in Israel". Ynetnew, August 30, 2020. https://www.ynetnews.com/articles/0,7340,L5009798,00.html (30 Ağustos 2020).

"Figures presented by Army show more Arabs than Jews live in Israel, West Bank and Gaza", Haaretz, Mar. 26, 2018. https://www.haaretz.com/israelnews/army-presents-figures-showing-arab-majority-in-israel-territories1.5940676 (Erişim Tarihi: 22 Ekim 2020).

"Israel Confronts Its Changing Demographic", Stratfor, Apr. 23, 2018. https://worldview.stratfor.com/article/israel-confronts-its-changingdemographics (Erişim Tarihi: 23 Ekim 2020).

“Israel's population to surge to 20 million by 2065", Arutz Sheva 7, May 22, 2017. https://www.israelnationalnews.com/News/News.aspx/229972 (Erişim Tarihi: 22 Ekim 2020).

“Israel's Religiously Divided Soviety, (March 2016)", Pew Research Center. https://www.pewforum.org/2016/03/08/israels-religiously-divided-society/ adresinden alındı.

"Israeli Military Chief Warns: Explosive Sensitive Situation Developing, Especially Among Palestinians", Haaretz, Mar. 28, 2018. https://www.haaretz.com/israel-news/.premium-idf-chief-of-staff-warnsthere-s-a-risk-of-an-escalation-this-year-1.5956331 (Erişim Tarihi: 22 Ekim 2020).

“issrail, Gazze'den neden çekildi?”, Deutsche Welle, August 17, 2005. https://www.dw.com/tr/israil-gazzeden-neden-\%C3\%A7ekildi/a-2524058 (Erişim Tarihi: 22 Ekim 2020).

"Jewish Population in Israel is Declining", Haaretz, Oct. 4, 2010. https://www.haaretz.com/1.5120784 (Erişim Tarihi: 22 Ekim 2020).

"Netanyahu Defends Egypt Border Fence: Influx of African Migrants More Dangerous Than Terorism", Haaretz, Mar. 20, 2020. https://www.haaretz.com/israel-news/.premium-netanyahu-danger-posed- 
by-african-migrants-is-greater-than-terrorism-1.5930984 (Erişim Tarihi: 22 Ekim 2020).

"Palestinian census: 4.7 million in West Bank and Gaza Strip", The Time of Israel, March 28, 2018. https://www.timesofisrael.com/palestinian-census-4-7million-in-west-bank-and-gaza-strip/ (Erişim Tarihi: 22 Ekim 2020).

"Palestinian Central Bureau of Statistics: Palestine in Figures 2016 (March 2017)", Ramallah; http://www.pcbs.gov.ps/Downloads/book2261.pdf adresinden alındı.

"Peace to Prosperity, January 2020", White House; https://www.whitehouse.gov/wp-content/uploads/2020/01/Peace-toProsperity-0120.pdf adresinden alındı.

"Statistics Bureau: A total of 4.780 .978 people live in Palestinian territories at end of 2017", Wafa, March 28, 2017. https://english.wafa.ps/page.aspx?id=NX8Ycoa97061674446aNX8Yco (Erişim Tarihi: 22 Ekim 2020).

"US Ambassador Warns Settlement Evacuation Could Spark Civil War", The Jerusalem Post, February 20, 2018. https://www.jpost.com/arab-israeliconflict/report-us-ambassador-warns-settlement-evacuation-could-sparkcivil-war-543084 (Erişim Tarihi: 22 Ekim 2020).

Al-Haj, M. (2004). Immigration and Ethnic Formation in a Deeply Divided Society: The Case of the 1990s Immigrants from the Former Soviet Union in Israel. Leiden-Boston: Brill.

Al-Rimmawi, H., Zeidan, E. (2013). Effect of Demographic Factor on PalestinianIsraeli Conflict. International Journal of Humanities and Social Science, 3(6), 214-224.

Avcı, Y. (2006). Siyon'dan Siyonizm'e: Politik bir İdeolojinin Dini Temelleri ve Fikri Gelişimi. Cumhuriyet Tarihi Araştırma Dergisi, 2(3), 43-58.

Avineri, S. (2017). The Making of Modern Zionism: The Intellectual Origins of the Jewish State. New York: Basic Book.

Aydın, E. (2010, 20 Temmuz). ìki Devlet mi? Tek Devlet mi? Yoksa Nehir'den Deniz'e kadar tek Filistin Devleti mi?. Dünya Bülteni Araştırma Masası. https://www.dunyabulteni.net/tarih-ve-toplum-konusmalari/iki-devlet-mi-tekdevlet-mi-h121246.html

Balcı, A. (2010). İsrail Sorunu: Ortadoğu'nun Gordion Düğümü, K. İnat, B. Duran ve M. Ataman (Ed.), Dünya Çatışmaları: Çatışma Bölgeleri ve Konuları (99163). İstanbul: Nobel Yayıncılık.

Balpınar, Z. (2019). İsrail Perspektifinden íki Devletli Çözüm. İstanbul Bilgi Üniversitesi Yayınları.

Bar-Haim, E. (2015). “Ethnic Stratification in Israel, In R. Saenz, D. D. Embtick ve N. P. Rodriquez (Eds.). The International Handbook of the Demography of Race and Ethnicity, New York: Springer.

Ben-David, D. (May 2019). Leaving the Promised Land. Shoresh Institution for Socioeconomic Research. 
Ben-David, D. (November 2018). Overpopulation and demography in Israel. Shoresh Institution for Socioeconomic Research.

Bunzl, J. (1988). Barış Hareketiyle Konuşmalar: Öteki İsrail. Metis Yayınları, ìstanbul.

Burston, B. "To the Settler Chief who insists Jews must rule Israel even if Arabs became the Majority", Haaretz, March 27, 2018, https://www.haaretz.com/opinion/.premium-to-the-settler-saying-jews-mustrule-israel-even-with-an-arab-majority-1.5955935 (Erişim Tarihi: 22 Ekim 2020).

Cook, J. "The deal of the century: US blessing for Israle's land theft and ghettoisation of the Palestinians. Middle East Eye", Middle East Eye, May 9, 2019. https://www.middleeasteye.net/opinion/israelthe-deal-century-simplyus-blessing-its-mass-theft-land-and-cantonisation (Erişim Tarihi: 10 Mayıs 2019).

Cox, P. R. (1976). Demography, London: Cambridge University Press,

Çalışkan, B. “Rusya'nın Sorunlu Federe Yapısı”, Anadolu Ajansı, 25 Mart 2020. https://www.aa.com.tr/tr/analiz/rusya-nin-sorunlu-federe-yapisi/1778656

(Erişim Tarihi: 22 Ekim 2020).

Çınkara, G. (2020). Yahudi Ulus Devlet Yasası ve İsrail'de Elitlerin Dönüşümü. Fiscaoeconomia, 4 (1), 191-202. https://doi.org/10.25295/fsecon.2020.01.010

Çulcu, M. (2012). Gelecek Yıl Kudüs'te: Siyonizmin İlk Dönemi 1895-1922. İstanbul: Kitap Deyince Yayınları.

Davis, R. A. (2016). Yerinde Edilen Coğrafyaları: Filistin Köy Tarihleri. Hayrullah Doğan (Çev.). İstanbul: Koç Üniversitesi Yayınları.

Della Pergola, S. (2018). World Jewish Population, 2018: Berman Jewish DataBank, Number 23, 1-68.

Della Pergola, S. (2011). Jewish Demographic Policies: Population Trends and Options in Israel and in the Diaspora. Jerusalem: The Jewish People Policy Institute.

Dikmen, Ö. (Nisan 2019). Siyonist Güvenlik Tahayyülünde Demografi Unsuru. Orsam Analiz, No: 228, 2-13.

Ediz, ì. (2015). Birinci Dünya Savaşı Sonrasında Filistin'de Toplum ve Siyaset. Türkiye Ortadoğu Çalışmaları Dergisi, 2(2), 141-176.

Ediz, i. (2019). A Neoclassical Realist Explanation of the Balfour Declaration and the Origins of the British Foreign Policy in Palestine. Tarih Incelemeleri Dergisi, XXXIV/I, 99-122.

Goldscheider, C. (1995). Population, Ethnicity and Nation-Building, Westview Press.

Goldscheider, C. (1992). Pupulation and Social Change in Israel, Westview Press.

Goldscheider, C. (1995) Ethnicity and Nation-Building in Israel: The Importance of Demographic Factor. in Calvin Goldscheider (Ed.). Population, Ethnicity and Nation-Building (s. 119-144) Westview Press.

Goldscheider, C. (1996). Israel's Changing Society: Population, Ethnicity and Development, Westview Press. 
Greilsammer, I. (2007). Siyonizm. Ankara: Dost Kitapevi.

Hawwash, K. "Deal of the century is a surrender note, and Palestinians will not sign", Middle East Eye, May 10, 2019. https://www.middleeasteye.net/opinion/deal-century-surrender-note-andpalestinians-will-not-sign (Erişim Tarihi: 11 Mayıs 2019).

Hertzberg, A, (1997). The Zionist Idea. The Jewish Publication Society.

Herzl, T. (1960). Complete Diaries of Theodor Herzl, New York.

Herzl, T. (2007). Yahudi Devleti. Sedat Demir (Çev.). İstanbul: Ataç Yayınları.

Hovsepian, M. (2015). Demography of Race and Ethnicity in Palestine. in R.

Saenz, D. D. Embtick ve N. P. Rodriquez (Eds.). The International Handbook of the Demography of Race and Ethnicity (pp. 339-353). New York: Springer.

https://www.yenisafak.com/yazarlar/zekeriyakursun/trumpin-pazara-dusen-planive-kuduste-statuko-merdiveni-2050319 (Erişim Tarihi: 10 Mayıs 2019).

Immell, M. (2010). Perspectives on Modern World History: The Creation of State of Israel. New York: Greenhaven Press.

İskit, T. (2017). Diplomasinin Gücü: Modern Ortadoğu'nun Şekillenmesi. İstanbul: İstanbul Bilgi Üniversitesi Yayınları.

Kahane, R. M. (1981). They Must Go. New York: Grosset\&Dunlap.

Kahane, R. M. (2012). The Ideology of Kach: the Authentic Jewish Idea. CreateSpace Independent Publishing Platform.

Kartin, M., Schnell, I. (2018). The Demographic Rogue and Borders in Land of Israel. Geopolitique et Populations, 3, 411-422:

\section{https://doi.org/10.4000/eps.3485}

Kasalak, K., Deveci, C. (2017). Paris Barış Konferansında Siyonistlerin Talepleri. Uluslararası Sosyal Araştırmalar Dergisi, 10(54), 298-306.

Kimmerling, B. (2001). The Invention and Decline of Israelines: State, Society, and the Millitary. Berkeley: University of California Press.

Kurşun, Z. "Trump'ın pazara düșen planı ve Kudüs'te statüko merdiveni”, Yeni Şafak, 9 Mayıs 2019.

Lustick, I. S. (2011). Israel's Migration Balance: Demography, Politics, and Ideology. Israel Studies Review, 26(1), 33-65.

Lustick, I. S. (2013). What Count is the Counting: Statistical Manipulation as a Splotion to Israel's Demographic Problem. Middle East Journal, 67(2), 185206.

Morris, B. (1991). The Origins of the Palestinian Refugee Problem. in L. J. Silberstein (Eds.). New Perspectives on Israeli History: The Early Years of the State, New York: New York University Press, 1991.

Morris, B. (2004). The Birth of the Palestinian Refugee Problem Revisited. Cambridge University Press.

Morris, B. (2009). One State, Two States: Resolving the Israel/Palestine Conflict. New Haven\&London: Yale University Press. 
Morris, B. (2012), 1948 Filistin Toplu Göçünü Yeniden İncelemek. Eugene L. Rogan, Avi Shlaim. (Ed.) Filistin Uğruna: 1948'in Tarihini Yeniden Yazmak, Suna Gülfer Ihlamur (Çev.). İstanbul: Küre Yayınları.

Neuman, S. (1999). Aliyah to Israel: Immigration under Conditions of Adversity. IZA.

Oruç, H. "A Deal to End All Deals? Trump's Deal of the Century May Annihilate Palestine", Politics Today, 1 June, 2019. https://politicstoday.org/a-deal-toend-all-deals-trumps-deal-of-the-century-may-annihilate-palestine) (Erişim Tarihi: 1 Haziran 2019).

Öke, M. K. (2013). Siyonizm ve Filistin Sorunu (1880-1923). İstanbul: Kırmızı Kedi.

Pappé, I. (2006). The 1948 Ethnic Cleansing of Palestine. Journal of Palestine Studies, 36(1), 6-20.

Pargola, S. D. (2011). Jewish Demographic Policies: Population Trends and Options in Israel and in Diaspora. Jerusalem: The Jewish People Policy Institute (JPPI).

Peretz, D., Doron, G. (1997). The Government and Politics of Israel. Westview Press.

Reinharz, J. (1991). The Transition from Yishuv to State: Social and Ideological Changes. in Laurence J. Silberstein (Ed.). New Perspectives on Israeli History. New York: New York University Press.

Ruderman, D. B. (2013). Erken Modern Dönem Yahudi Tarihi. Lizet Deadato (Çev.). İstanbul: İnkılâp Yayınevi.

Saenz, R. Embrick, D. G. ve Rodriquez, N. P. (Eds.) (2015). The International

Handbook of the Demography of Race and Ethnicity. New York: Springer.

Shahak, I. (2015). Yahudi Devleti Yahudi Tarihi. İstanbul: Düşün Yayıncılık.

Shapira, A. (2012). Israel a History. Waltham, MA: Brandeis University Press.

Statistical Abstract of Israel (1992). Jerusalem: Government of Israel, Central Bureau of Statistics.

Tal, A. (2016). The Land is Full: Addressing Overpopulation in Israel. New Haven. CT:Yale University Press.

Tellioğlu, Ö. (2014). Filistin'e Musevi Göçü, Arazi Satışı ve Kolonileşme Sürecinde Uygulanan Yöntemler. Osmanlı'dan Günümüze Filistin Sempozyumu (28-29 Kasım 2013) 1, Ankara: Türk Tarih Kurumu, 185-205.

Tomar, C. "Yüzyılın anlaşması ya da yüzyılın işgali”, Anadolu Ajansı, 9 Mayıs 2019. https://www.aa.com.tr/tr/analiz/yuzyilin-anlasmasi-ya-da-yuzyilinisgali/1474215 (Erişim Tarihi: 10 Mayıs 2020).

Tuygan, A. "Deal of the Century", Edam, February 3, 2020. https://edam.org.tr/en/deal-of-the-century/ (Erişim Tarihi: 3 Şubat 2020).

Weiner M., Russell, S. S. (Eds). (2001). Demography and National Security. New York: Berghahn Books.

White, B. "UN report: Israel has established an apartheid regime", Aljezeera. March 18, 2017. https://www.aljazeera.com/features/2017/3/18/un-reportisrael-has-established-an-apartheid-regime (Erişim Tarihi: 23 Ekim 2020). 